\title{
1. Introduction: EU agencies going global
}

\section{Merijn Chamon, Herwig C.H. Hofmann and Ellen Vos}

\section{EU AGENCIES RESEARCH: TAKING STOCK}

More than 40 years experience with the EU decentralized agencies has made clear that the agencies are part and parcel of the EU's institutional structure. These agencies can broadly be defined as bodies governed by European public law that are institutionally separate from the EU institutions, have their own legal personality, enjoy a certain degree of administrative and financial autonomy, and have clearly specified tasks. 'Agencification' of EU executive governance has thus become a fundamental feature of the EU's institutional structure. Today there are around $40 \mathrm{EU}$ decentralized agencies, which assist in the implementation of EU law and policy, provide scientific advice for both legislation and implementation, collect information, provide specific services, adopt binding acts and fulfil central roles in the coordination of national authorities. Agencies are part of a process of functional decentralization within the EU executive and operate in various policy fields, such as food and air safety, medicines, environment, telecommunications, disease prevention, border control, trademarks and banking, to name just a few. ${ }^{1}$

Thus far, research on agencification has mainly focused on identifying and understanding agencies' function as contributing to the proper implementation and further development of the EU acquis. ${ }^{2}$ In a recent review article taking

1 Ellen Vos, 'European agencies and the composite EU executive' in Everson, Monda and Vos (eds), European Agencies in Between Institutions and Member States (Alphen aan den Rijn: Wolters Kluwer, 2014), 11-47.

${ }_{2}$ See, among others, Michael Kaeding and Esther Versluis, 'EU Agencies as a Solution to Pan-European Implementation Problems' in Everson, Monda and Vos (eds), European Agencies in Between Institutions and Member States (Alphen aan den Rijn: Kluwer Law International, 2014) 73, 73-86; Marco Scipioni, 'De Novo Bodies 
stock of the burgeoning agencification literature, Trondal and Egeberg conclude that:

agencification of the EU administration may be regarded as a compromise between functional needs for the supply of more regulatory capacity at the European level, on one hand, and Member States' reluctance to transfer executive authority to the European Commission on the other. ${ }^{3}$

In the traditional terms of EU integration studies, agencies are a compromise between supranationalism and intergovernmentalism. On the one hand, Member States realize that in order to give proper effect to commonly agreed EU policies (at the legislative level), some common EU action in the implementation phase (ie, administrative integration) is required. On the other hand, Member States resist the default option prescribed by the EU Treaties to this end, since this would require expanding the supranational Commission. ${ }^{4}$

Focusing on the functional reasons for resorting to agencies shows that because EU agencies have been established to ensure a more proper and uniform implementation of EU law, EU agencies essentially have an inward function. As a result, academic research on agencification has also focused almost exclusively on issues internal to the EU legal order. This by now incredibly rich body of research in areas such as public administration, political science and law has focused on a breadth of topics.

For example, questions have been raised as to how subsidiary bodies such as agencies should be properly conceptualized in both the EU multi-level legal order ${ }^{5}$ and the EU administration or the European administrative space. ${ }^{6}$

and EU Integration: What is the Story behind EU Agencies' Expansion?', [2018] JCMS 4 768, 768-784.

3 Morten Egeberg and Jarle Trondal, 'Researching European Union Agencies: What Have We Learnt (and Where Do We Go from Here)?', [2017] JCMS 4 675, 675.

4 The Treaties (Article 291 of the Treaty on the Functioning of the European Union) also allow the Council to take on an implementing role, but - apart from the fact that this is only so in exceptional cases - the Council lacks the governance structure to fulfil the functional need of a more uniform implementation of EU law.

5 Morten Egeberg and Jarle Trondal, 'EU-level agencies: new executive centre formation or vehicles for national control?', [2011] JEPP 6 868, 868-887; Ellen Vos, 'European agencies and the composite EU executive' in Everson, Monda and Vos (eds), European Agencies in Between Institutions and Member States (Alphen aan den Rijn: Kluwer Law International, 2014) 11, 11-47; Eva Heidbreder, 'Strategies in multilevel policy implementation: moving beyond the limited focus on compliance', [2017] JEPP 9 1367, 1367-1384; Torbjørg Jevnaker, 'Pushing administrative EU integration: the path towards European network codes for electricity', [2015] JEPP 7 927, 927-947.

6 Herwig Hofmann, Gerard Rowe and Alexander Türk, Administrative Law and Policy of the European Union (OUP, 2011), 977; Alie de Boer, Miriam Urlings, Ellen Vos and Aalt Bast, 'Enforcement of the nutrition and health claim regulation', [2015] 
Other authors have focused on the question of why agencies are sometimes preferred over looser forms of administrative integration such as networks (or vice versa). ${ }^{7}$ The fact that the EU agencies are semi-detached from the main EU institutions raises questions as to the actual degree of their autonomy ${ }^{8}-$ an issue which has as its corollary the question of their accountability. ${ }^{9}$

In legal research, the main topic has been the question of how to conceptualize the delegation of powers to the EU agencies and how to fit the agencies into the EU's constitutional framework. ${ }^{10}$ This links with political science

EFFLR 5 334, 334-344; Jarle Trondal and Lene Jeppesen, 'Images of Agency Governance in the European Union', [2008] WEP 3 417, 417-441; Rik Joosen and Gijs Jan Brandsma, 'Transnational executive bodies: EU policy implementation between the EU and member state level', [2017] Public Administration 2 423, 423-436.

7 Daniel Kelemen and Andrew Tarrant, 'The Political Foundations of the Eurocracy', [2011] WEP 5 922, 922-947; Mark Thatcher, 'The creation of European regulatory agencies and its limits: a comparative analysis of European delegation', [2011] JEPP 6 790, 790-809; Sarah Wolff and Adriaan Schout, 'Frontex as Agency: More of the Same?', [2013] Perspectives on European Politics and Society 3 305, 305-324; David Levi-Faur, 'Regulatory networks and regulatory agencification: towards a single European regulatory space', [2011] JEPP 6 810, 810-829; Michael Blauberger and Berthold Rittberger, 'Conceptualizing and theorizing EU regulatory networks', [2015] Regulation \& Governance 4 367, 367-376.

8 Martijn Groenleer, The Autonomy of European Union Agencies: A Comparative Study of Institutional Development (Delft: Eburon, 2009), 432; Maria Martens, 'Voice or Loyalty? The Evolution of the European Environment Agency (EEA)', [2010] JCMS 4 881, 881-901; Arndt Wonka and Berthold Rittberger, 'Credibility, complexity and uncertainty: explaining the institutional independence of 29 EU agencies', [2010] WEP 4 730, 730-752; Ellen Vos, 'EU agencies and independence' in Ritleng (ed), Independence and Legitimacy in the Institutional System of the European Union (Oxford: OUP, 2016) 206, 206-227.

9 Madalina Busuioc, 'European agencies and their boards: promises and pitfalls of accountability beyond design', [2012] JEPP 5 719, 719-736; Madalina Busuioc, European Agencies - Law and Practices of Accountability (Oxford: OUP, 2013); Michael Buess, 'Accountable and Under Control? Explaining Governments' Selection of Management Board Representatives', [2015] JCMS 3 493, 493-508; Nuria Font and Ixchel Pérez Durán, 'The European Parliament oversight of EU agencies through written questions', [2016] JEPP 9 1349, 1349-1366; Miroslava Scholten, The Political Accountability of EU and US Independent Regulatory Agencies (Brill, Leiden, 2014); Christopher Lord, 'The European Parliament and the legitimation of agencification', [2011] JEPP 6 909, 909-925; Julia Jansson, 'Building resilience, demolishing accountability? The role of Europol in counter-terrorism', [2016] Policing and Society 4 432, 432-477; Michael Buess, 'European Union Agencies' Vertical Relationships with the Member States: Domestic Sources of Accountability', [2014] Journal of European Integration 5 509, 509-524.

10 Herwig Hofmann and Alessandro Morini, 'Constitutional Aspects of the Pluralisation of the EU Executive through "Agencification", [2012] ELRev 4 419, 419-443; Michelle Everson and Ellen Vos, 'European Agencies: What about the 
research on the relation between the EU agencies and the Commission ${ }^{11}$ or stakeholders, ${ }^{12}$ and the role of specific agencies in the EU's policies. ${ }^{13}$ In still other research, the EU agencies are the object of case studies in their own right or are used as case studies to test a number of hypotheses deduced from general theories on regional integration. ${ }^{14}$

institutional balance?' in Blockmans and Lazowski (eds), Research Handbook EU Institutional Law (Cheltenham: Edward Elgar Publishing, 2016) 139, 139-155; Merijn Chamon, EU Agencies: Legal and Political Limits to the Transformation of the EU Administration (Oxford: OUP, 2016); Katja Michel, Institutionelles Gleichgewicht und EU-Agenturen (Berlin: Duncker \& Humblot, 2015); Andreas Orator, Möglichkeiten und Grenzen der Einrichtung von Unionsagenturen (Tübingen: Mohr Siebeck, 2017); Jacopo Alberti, Le Agenzie dell'Unione europea (Milan: Giuffrè, 2018); Carlo Tovo, Le agenzie decentrate dell'Unione europea (Naples: Editoriale Scientifica, 2016).

11 Daniel Fiott, 'The European Commission and the European Defence Agency: A Case of Rivalry?', [2015] JCMS 3 542, 542-557; Morten Egeberg, Jarle Trondal and Nina M Vestlund, 'The Quest for Order: Unravelling the Relationship between the European Commission and European Union Agencies', [2015] JEPP 5 609, 609-629.

12 Sarah Arras and Caelesta Braun, 'Stakeholders wanted! Why and how European Union agencies involve non-state stakeholders', [2018] JEPP 9 1257, 1257-1275; Ixchel Pérez Durán, 'Political and stakeholder's ties in European Union agencies', [2019] JEPP 1 1, 1-22.

13 Martijn Groenleer, Michael Kaeding and Esther Versluis, 'Regulatory governance through agencies of the European Union? The role of the European agencies for maritime and aviation safety in the implementation of European transport legislation', [2010] JEPP 8 1212, 1212-1230; Esther Versluis and Erika Tarr, 'Improving Compliance with European Union Law via Agencies: The Case of the European Railway Agency', [2013] JCMS 2 316, 316-333; Gabriel Toggenburg and Jonas Grimheden, 'Upholding Shared Values in the EU: What Role for the EU Agency for Fundamental Rights?', [2016] JCMS 5 1093, 1093-1104; Alicia Hinarejos, 'A Missed Opportunity: The Fundamental Rights Agency and the Euro Area Crisis', [2016] ELJ 1 61, 61-73.

14 For learning theory and principal agent theory, see Anthony Zito, 'European agencies as agents of governance and EU learning', [2009] JEPP 8 1224, 1224-1243; On principal agent theory, see Daniel Keleman, "The Politics of "Eurocratic" Structure and the New European Agencies', [2002] WEP 4 93, 93-118; Florian Trauner, 'The European Parliament and Agency Control in the Area of Freedom, Security and Justice', [2012] WEP 4 784, 784-802. For institutionalization theory, see Jon Pierre and Guy Peters, 'From a club to a bureaucracy: JAA, EASA, and European aviation regulation', [2009] JEPP 3 337, 337-355. For structural choice theory, see Jørgen Grønnegaard Christensen and Vibeke Lehmann Nielsen, 'Administrative capacity, structural choice and the creation of EU agencies', [2010] JEPP 2 176, 176-204. For rational choice theory, see Björn Fägersten, 'Bureaucratic Resistance to International Intelligence Cooperation - The Case of Europol', [2010] Intelligence and National Security 4 500, 500-520. For socialization theory, see Semin Suvarierol, Madalina Busuioc and Martijn Groenleer, 'Working for Europe? Socialization in the European Commission and Agencies of the European Union', [2013] Public Administration 4 908, 908-927; Arndt Wonka and Berthold Rittberger, 'Perspectives on EU governance: 


\section{EU AGENCIES RESEARCH: THE EXTERNAL DIMENSION}

Without pretending to have presented an exhaustive or even representative overview of this vibrant research field, it was already noted that the existing research has almost exclusively focused inward. This is unsurprising in view of the fundamental role played by the agencies in various EU policies. However, the agencies are becoming increasingly active at the international level, as it has become very clear that in order for them to fulfil their mandate, they need to interact with third countries, international organizations and other non-EU bodies. Indeed, most agencies' establishing acts refer in one way or another to the agency's external action, although the relevant provisions governing this action are remarkably succinct even for those agencies that have developed elaborate external relations.

Hence, for a few years, there has been growing interest among scholars in the external dimension of agencification. Consequently, pioneering research has been carried out by various scholars to gain an understanding of what it is precisely that agencies do at the global level, in both functional and legal terms. ${ }^{15}$ The current practice of the agencies on the international stage, as revealed by this research, involves a variety of actions that are closely linked with their mandate and powers in their respective founding regulations. For example, the agencies collaborate in training matters, organize common events to share know-how and capacity-building activities, while also developing common procedures, exchanging information and personal data and carrying out joint operations. ${ }^{16}$ The agencies are further active in setting standards and ensuring mutual recognition and incorporation of international best practices

an empirical assessment of the political attitudes of EU agency professionals', [2011] JEPP 6 888, 888-908.

15 For pioneering work, see, among others, Martijn Groenleer and Simone Gabbi, 'Regulatory Agencies of the European Union as International Actors', [2013] EJRR 4 479, 479-492; Andrea Ott, Ellen Vos and Florin Coman Kund, 'European agencies on the global scene: EU and international law perspectives' in Everson, Monda and Vos (eds), European Agencies in Between Institutions and Member States (Alphen aan den Rijn: Kluwer Law International, 2014) 87, 87-122; Sandra Lavanex, 'The external face of differentiated integration: third country participation in EU sectoral bodies', [2015] JEPP 6 836, 836-853; Florin Coman-Kund, European Union Agencies as Global Actors. A Legal Study of the European Aviation Safety Agency, Frontex and Europol (London: Routledge, 2018).

16 Andrea Ott, Ellen Vos and Florin Coman-Kund, 'European agencies on the global scene: EU and international law perspectives' in Everson, Monda and Vos (eds), European Agencies in Between Institutions and Member States (Alphen aan den Rijn: Kluwer Law International, 2014) 87, 87-88. 
and standards of scientific knowledge. In order to do so, the agencies enter into more or less binding arrangements of a sometimes not entirely well-established legal nature.

In view of this diversity of activities, this book contributes in an inter-disciplinary way to fostering and showcasing research on the external dimension of the EU agencies, as well as developing questions for further research. The different chapters present a cross-section view of the different research strands currently developing in political and legal science on the external relations of the EU agencies, at the same time giving a taste of the breadth of issues where knowledge remains thin or non-existent and suggesting that these gaps be filled in order to contribute to a future research agenda.

\section{BOOK CHAPTERS}

In Chapter 2, Chamon and Demedts sketch out the constitutional framework that governs, or ought to govern, the external action of the EU agencies. To this end, they first analyse the positive law, including Treaty provisions, norms resulting from the agencies' establishing acts, the Common Approach on Decentralised Agencies and the working arrangements concluded between agencies and their parent Directorates General. They then deduce limits from the principles of conferral and institutional balance, as well as the Meroni doctrine and more recent jurisprudence of the Court. Bringing together these elements, Chamon and Demedts identify preliminary findings that raise new questions for future research - one of the main questions today being whether the specific administrative agreements concluded by individual agencies with third country counterparts (or international organizations) conform to the identified composite legal framework.

Chapter 3 by Coman-Kund takes up part of this research agenda by building on his earlier work and by scrutinizing the 2016 Frontex Regulation (recast following and in light of the migration crisis) and the working arrangements concluded by Frontex against some of the constitutional limits identified by Chamon and Demedts. Frontex is indeed one of the (few) EU agencies for which external action is part of its core mandate, as reaching out to the EU's neighbours is necessary to properly secure the Schengen zone's external borders. Coman-Kund shows how the new 2016 Frontex Regulation has not radically altered the international mission of the agency and how its external action is generally compliant with the constitutional limits. At the same time, Coman-Kund identifies some salient issues - notably the possibility for Frontex to conduct operational activities on third countries' territories, which merits further scholarly attention.

In a second chapter on the Area of Freedom, Security and Justice (AFSJ), Brière addresses in Chapter 4 the cooperation of Europol and Eurojust with 
external partners in the fight against crime and discusses the recently revised legal frameworks organizing the modalities of Europol's and Eurojust's external cooperation. She finds that the revision was necessary to modernize the agencies' frameworks following the entry into force of the Lisbon Treaty and to come to a greater degree of harmonization. The chapter identifies two challenges of the agencies' external activities: the diversity in their relations with external partners, and the need to ensure an appropriate balance between efficient cooperation and protection of fundamental rights. Brière thereby identifies two further parts of the future research agenda in this field: first, whether the new legal framework allows the EU agencies to produce sufficient policy output; and second, whether the new legal framework and the possibilities for data transfer in the absence of an adequacy decision strike the right balance (in practice) between the right to privacy on the one hand and security cooperation on the other.

In Chapter 5 by Ekelund, Manner's 'Normative Power Europe' is applied to Frontex through a critical analysis of the agency's founding regulation and working arrangements. As Ekelund notes, her findings are preliminary. However, on the basis of her ongoing research, she concludes encouragingly that fundamental rights take a central role in Frontex's relevant legislative framework, and that there is a high level of consistency within the provisions relating to fundamental rights. However, the author notes herself that further research is necessary to determine whether the agency implements its mandate on the ground in conformity with its own 'discourse' and how it manages possible conflicting expectations. Evidently, it would be useful to make a similar horizontal assessment for the other agencies working in the AFSJ.

Chapter 6 by Chatzopoulou relies on organization theory to study EU policy promotion beyond the EU's borders by the EU agencies and suggests that they acquire organization structural characteristics that enhance the agencies' role in the international arena with respect to the diffusion of policy ideas, principles, practices and policy models. The EU agencies develop their own capacity, interests and strategies; organize international arrangements; and become actors with the intention to diffuse policy ideas and standards beyond the EU. Chatzopolou's findings raise the questions of whether the structural characteristics have general predictive value and whether a relationship can also be established between the actual impact of the agencies' external activities and the structural characteristics which she has identified.

In Chapter 7 De Bellis develops a case study on the - for the EU agencies - traditional field of tension between formal legitimacy and output legitimacy and this in the area of financial standards where a number of key international bodies are active. These bodies adopt soft law which is later incorporated into domestic law. To ensure that the EU can effectively contribute to shaping international norms, it should be represented in these forums by the most 
appropriate actors, which typically would be the EU agencies. However, in addition to the problematic formal legitimacy of the reception of international soft law standards, the EU is also confronted here with the problematic formal legitimacy of the EU agencies involved. While De Bellis rightly stresses the need to ensure accountability and transparency of these processes in the short term, the questions implicitly raised by De Bellis highlight the need to address this area of tension in a more sustainable and long-term manner.

In Chapter 8 Van Cleynenbreugel notes a trend whereby the agencies are increasingly called upon to assess in one way or another the equivalence of third country legal regimes. Van Cleynenbreugel offers an overview of the equivalence procedures in place before reflecting on the accountability challenges specific to those procedures. One of the challenges identified is that of a particular gap in the accountability features. The chapter ends by elaborating a future research agenda to overcome the identified gap, centred on three main questions.

Inglese focuses in Chapter 9 on the role which the European Ombudsman can play in securing good administration in the EU agencies' external relations. His finding of a positive influence of decisions of the Ombudsman so-called 'ombudsprudence' - on the EU agencies' external actions generally contributes to our understanding of the relationship between the European Ombudsman and the EU agencies, and how the EU agencies perceive this relationship themselves. This picture, which focuses on accountability at the EU level, should be complemented by future research in order to sufficiently take into account the multi-level nature of EU administration. Indeed, given the composite nature of many EU administrative procedures, a holistic view of good administration should add the cooperation between the European Ombudsman and the Network of European Ombudsmen to the equation.

In Chapter 10 Rimkute and Shyrokykh address the question of how the EU agencies can fulfil a role in exporting the EU acquis to third countries. They focus on the European Neighbourhood Policy and build a theoretical argument explaining the varying degrees of third country cooperation by the EU agencies. They contrast a foreign policy dynamic with a functional interdependence dynamic. Further empirical research is needed to test these findings. The authors themselves also note that further research should seek to review whether third country norms are actually subject to change due to the influence exercised in the context of cooperation mechanisms, and whether the results of such cooperation end up in alignment with EU norms. A further follow-up question is then whether such norms are also properly implemented and enforced in third countries.

Chapter 11 by Öberg changes the perspective and looks at the EU agencies from the perspective of third countries: what is their interest in participating as third countries in an EU body and under which constellations is this pos- 
sible? Can third countries, through their participation, actually influence (or 'shape') the EU acquis which they either unilaterally or contractually (through an international agreement with the EU) agree to adopt themselves? Öberg explores this issue and puts forward the hypothesis that the possibility to shape is a function of both the agency's capacity to influence the acquis and the third country's possibility to contribute to the work of the agency. This finding calls for empirical case studies aimed at falsifying and refining this hypothesis.

\section{SETTING A RESEARCH AGENDA}

The chapters in this book outline a fascinating research agenda in a nascent field of research dealing with the external relations of the EU agencies. The chapters clearly confirm the need for further research on many aspects of the agencies' role in the international arena and on their mandates, organizational structures and behaviour, as well as what might be called their 'actorness'. It is also true that there is still a lack of raw information on how the EU agencies operate in the relevant policy areas at the international level. Different chapters thus stress the need for more in-depth and empirical research on the activities of agencies such as Frontex, Europol and Eurojust, as well as the cooperation between the EU agencies and European Neighbourhood Policy countries.

Moreover, the findings put forward in the chapters raise a set of general legal questions which remain largely unresolved. These include, inter alia, the exact understanding of constitutional limits of agency powers in the international sphere, the specific nature of administrative arrangements that agencies conclude and the criteria for assessing the legality of agencies' activities (eg, operational activities conducted by Frontex in third countries' territories). Other areas that require further in-depth research include the tension between fundamental rights, data protection and security cooperation in the fight against terrorism and organized crime.

More generally, the chapters in this book point to the need to deepen research into questions of legitimacy and accountability of the external actions of EU agencies. One example is the question of the formal legitimacy of the reception of international soft law standards into EU law. Here the EU agencies may effectively contribute to shaping international norms; however, how this may be done and how this impacts on the legitimacy of agency action at the EU level is still unclear. Another example is the cooperation that the agencies will undertake in the context of today's generation of free trade agreements, which include requirements of regulatory cooperation and mutual recognition of standards. Accountability of agency action is a matter to be studied not only in relation to inward activities, but also in relation to external actions, as various chapters in this book show. It is therefore unsurprising that the right to good administration is mentioned throughout this book as relevant 
also for the external actions of agencies. At the same time, it is apparent that the various procedures to establish the equivalence of third country legal rules or regimes with EU regulatory standards also require further reflection on the accountability challenges specific to those procedures.

The ongoing scholarly debate on the EU agencies to which this book contributes is thus only one step towards illuminating this fascinating field of EU external action and EU administrative law scholarship. We hope it will inspire and encourage scholars to do further research in relation to the external dimension of the EU agencies activities, as set forth in this research agenda. 